\title{
Integrating brand, retailer and end-customer perspectives
}

\author{
Mark Glynn Auckland University of Technology, New Zealand
}

\begin{abstract}
With increased retailer concentration, competition and the emphasis on private labels, it is easy to assume that manufacturers' brands are less important to retailers. Retailers manage their stores as brands and control the brand offering inside the store, coordinating the manufacturer's brand with the private label. However manufacturers' brands are still important in determining retailer profitability and store image. This research paper seeks to clarify the value of manufacturers' brands to retailers within marketing channel relationships. Key words: Manufacturers' brands, retailers, channel relationships
\end{abstract}

The success of most brands involves external channel support (Leone et al., 2006) in addition to the firm's marketing mix as well as consumer attitudes and behaviour (Keller, 2003). Channel support involves many sub-processes (Lambert and García-Dastugue, 2006) within supply chain relationships, but research in this area typically addresses the manufacturerretailer dyad. In a review of the literature on consumer response to brand marketing activity, Hoeffler and Keller (2006) highlight the lack of research into brand equity within marketing channels. However several authors (Moreau et al., 2001; Webster, 2000; Glynn et al., 2007) recognize that a wider perspective i.e. the manufacturer-retailer-consumer triad is needed. This perspective includes the manufacturer's brand as well as the end-customer.

Value creation between manufacturers and retailers therefore involves many external operational linkages or processes for the manufacturer. Examples of these processes include brand management to stimulate end customer demand for the brand (the brand to endcustomer link) and key account management, which ensures the representation of the manufacturer's brand interests in the channel (the brand to retailer link). Manufacturers should also recognize the many retail processes involved including retailers managing their own stores as brands (Grewal et al., 2004), controlling the brand offering inside the store and coordinating the manufacturer's brand with the store brand (Dawson, 2006) (the retailer to customer link).

From a retailer's perspective the manufacturer's brand is a resource that provides value to their customers (Hunt et al., 2006). In branding terminology such a resource becomes an 'ingredient' brand for the retailer (Ailawadi and Keller, 2004) and customer 'bait' (Leone et al. 2006). Srivastava et al. (1998) use the term market-based assets to describe how these 
resources produce a sustainable competitive advantage for firms. In channels of distribution these market-based assets are embedded in inter-organizational routines (Dyer and Singh, 1998). It is recognized that inter-firm relationships are necessary to fully leverage the value of these assets (Subramani and Venkatraman, 2003). These inter-organisational sources of advantage (Dyer and Singh, 1998) include: (examples of brand resources in brackets) relational specific assets (brand equity), knowledge sharing (brand market information) complementary resources (brand marketing expenditure) and effective governance (sales force and cooperative advertising expenditure).

However, retailer decisions about a manufacturer's brand can affect a brand's performance (Buchanan et al., 1999). Examples of such decisions include a brand's display placement and shelf location within the store. Verbeke et al. (2006) find that a manufacturer's brand strength influences retail shelf allocation and promotion decisions.

Research conducted by Glynn et al. (2007) shows that manufacturer brands benefit retailers in several ways: first the financial benefits from reselling the brand, second the manufacturer's support of the retailer, third customer expectations and finally brand equity considerations. The financial benefit reflects the transactional aspects of brands for retailers such as volume, profit and pricing. The manufacturer support benefit highlights the brand marketing mix effects including advertising support. Retailers also consider that manufacturer support for retail store promotions is vital with some commenting that 'a brand rarely sells by itself'. Manufacturer brands allow retailers to offer a wide assortment to their customers, that retailers cannot provide by themselves. The brand's marketing mix also stimulates the product category for the retailer and manufacturers often provide retailers market and category information. The remaining benefits stem from the expectation of the retailer's customers that the brand will be available in store and the equity of the manufacturer's brand.

This research also reveals that retailer satisfaction with the manufacturer's brand is a key relational outcome. Retailer brand satisfaction in turn influences the retailer's trust of the manufacturer, cooperation on matters concerning the brand, dependence on the manufacturer, commitment to the brand, and assessing the brand performance within the store. However some relationship outcomes are attributable more to the manufacturer than the brand itself. Retailers are more likely to cooperate with, depend on or trust a manufacturer on matters concerning the brand. In contrast, outcomes such as satisfaction, commitment and 
performance are more readily attributable by retailers to the brand itself rather than to the manufacturer.

From this research a conceptual framework was developed and tested showing the effects of manufacturer benefits on retailer brand satisfaction and other relationship constructs (Glynn and Brodie, 2004). Three manufacturer brand benefits for retailers were evident in the data: manufacturer brand support, brand equity and consumer expectations of the brand. Manufacturer brand support was the most influential benefit on retailer brand satisfaction followed by consumer expectations and then brand equity. Retailer brand satisfaction influences retailer commitment to the brand, performance and trust in the manufacturer on matters concerning the brand.

Within this framework two moderating variables, brand strength and the product category, were also examined. The results confirmed that brand strength is a moderating variable between the brand benefits and relationship variables. Retailers were more likely to be committed to low equity brands and trust the manufacturer on matters concerning the brand in contrast to high equity brands. The research shows the role of minor brands in expanding the assortment and counterbalancing the dependence on manufacturer for the retailer. Product category differences between the brands in the high value wine and beer categories and the lower value grocery product categories were then assessed. Wine and beer brands were more likely to achieve a better brand performance rating in comparison to grocery brands (Glynn, 2007). Thus manufacturers need to be aware that a retailer's evaluation of a brand depends on the product category.

There have been few attempts in the literature to examine brands from the perspective of the retailer. This research project clarifies the nature of channel support for the manufacturer brand. The findings show that this channel support is a function of three brand benefits which influence retailer satisfaction which include both the end-customer and the manufacturer's brand (Leone et al., 2006). This research integrates the manufacturer's brand and the endcustomer from the retailer's perspective as well as identifying key moderating variables. The conceptual framework is also applicable to other B2B relationships where brands are pivotal such as franchising, co-branding, and the supply of private label brands. 


\section{References:}

Ailawadi, K. L. and Keller K. L. (2004) 'Understanding Retail Branding: Conceptual Insights and Research Priorities', Journal of Retailing, 80(4): 331-42.

Buchanan, L., Simmons C. J. and Bickart B. A. (1999) 'Brand Equity Dilution: Retailer Display and Context Effects', Journal of Marketing Research, 36(3): 345-55.

Dawson, J. (2006) Retail Trends in Europe. In Krafft, M. and Mantrala, M. K. editors, Retailing in the 21st Century: Current and Future Trends, pp. 41-58. New York: Springer.

Dyer, J. H. and Singh, H. (1998) 'The Relational View: Cooperative Strategy and Sources of Interorganizational Competitive Advantage', Academy of Management Review, 23(4): 66079.

Glynn, M. S. and Brodie, R. J. (2004) 'The Role of Brands in Creating Value in SupplierReseller Relationships', paper presented at the 33rd EMAC conference, Murcia, Spain, May.

Glynn, M. S., Motion, J. M. and Brodie, R. J. (2007) 'Sources of Brand Benefits in Manufacturer-Reseller B2B Relationships', Journal of Business and Industrial Marketing, 22(6): 400-09.

Glynn, M. S. (2007) 'How Retail Category Differences Moderate Retailer Perceptions of Manufacturer Brands', Australasian Marketing Journal, 15(2): 55-67.

Grewal, D., Levy, M. and Lehmann D. R. (2004) 'Retail Branding and Customer Loyalty: An Overview'. Journal of Retailing, 80(4): ix-xii.

Hoeffler, S., and Keller, K. L. (2003) 'The Marketing Advantages of Strong Brands', Journal of Brand Management, 10(6), 421-45.

Hunt, S. D., Arnett D. B. and Madhavaram S. (2006) 'The Explanatory Foundations of Relationship Marketing Theory', Journal of Business and Industrial Marketing, 21(2): 72-87.

Keller, K. L. (2003) Strategic Brand Management: Building, Measuring, and Managing Brand equity. 2nd ed. Upper Saddle River, N.J.: Prentice Hall.

Lambert, D. M. and García-Dastugue S. J. (2006) 'Cross-Functional Business Processes for the Implementation of Service-Dominant Logic'. In Lusch, R. F. and S. L. Vargo, editors, The Service-Dominant Logic of Marketing: Dialog, Debate, and Directions, pp 150-165. Armonk, N.Y.: M.E. Sharpe.

Leone, R.P., Rao V.R., Keller, K. L., Luo, A. M., McAlister, L. and Srivastava R. (2006) 'Linking Brand Equity to Customer Equity', Journal of Service Research, 9(2): 125-38.

Moreau, P., Krishna A., and Harlam, B. (2001) 'The Manufacturer-Retailer-Consumer Triad: Differing Perceptions Regarding Price Promotions'. Journal of Retailing, 77(4): 547-69. 
Srivastava, R., Shervani, T. A. and Fahey, L. (1998) 'Market-Based Assets and Shareholder Value: A Framework for Analysis', Journal of Marketing, 62(1): 2-18.

Subramani, M. R. and Venkatraman, N. (2003) 'Safeguarding Investments In Asymmetric Interorganizational Relationships: Theory And Evidence', Academy of Management Journal, 46(1): 46-62.

Verbeke, W., Bagozzi, R. P. and Farris, P. (2006) 'The Role of Key Account Programs, Trust, and Brand Strength on Resource Allocation in the Channel of Distribution', European Journal of Marketing, 40(5/6): 502-32.

Webster, F. E. (2000) 'Understanding the Relationships among Brands, Consumers, and Resellers', Journal of the Academy of Marketing Science, 28(1): 17-23.

Mark S. Glynn is a Senior Lecturer in the AUT Business School at the Auckland University of Technology. He obtained his $\mathrm{PhD}$ in marketing from the University of Auckland. His research interests include branding, business-to-business marketing and retail channels. His published research has appeared in the Journal of Business and Industrial Marketing, Journal of Product and Brand Management, Marketing Theory and the Australasian Marketing Journal. He also serves on the Editorial Boards of Industrial Marketing Management and the Journal of Business and Industrial Marketing. Address: Department of Marketing, AUT Business School, Auckland University of Technology, Private Bag 92006, Auckland 1142, New Zealand. [Email: mark.glynn@aut.ac.nz] 